\title{
Summary of carbon, nitrogen, and iron leaching characteristics and fluorescence properties of materials considered for subseafloor observatory assembly ${ }^{1}$
}

Beth N. Orcutt, ${ }^{2,3}$ Roman A. Barco, ${ }^{3}$ Samantha B. Joye, ${ }^{4}$ and Katrina J. Edwards ${ }^{2,5}$

\section{Chapter contents}

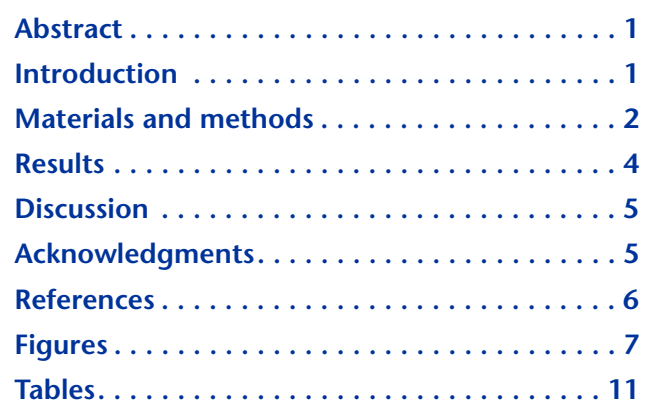

'Orcutt, B.N., Barco, R.A., Joye, S.B., and Edwards, K.J., 2012. Summary of carbon, nitrogen, and iron leaching characteristics and fluorescence properties of materials considered for subseafloor observatory assembly. In Edwards, K.J., Bach, W., Klaus, A., and the Expedition 336 Scientists, Proc. IODP, 336: Tokyo (Integrated Ocean Drilling Program Management International, Inc.). doi:10.2204/iodp.proc.336.108.2012

'Expedition 336 Scientists' addresses.

${ }^{3}$ University of Southern California, 3616 Trousdale Parkway, Los Angeles CA 90089, USA.

${ }^{4}$ Department of Marine Sciences, University of Georgia, Athens GA 30602-3636, USA.

${ }^{5}$ Correspondence author: kje@usc.edu

\section{Abstract}

To limit the potential for metal contamination in crustal subsurface borehole observatories, fiberglass and resin-coated steel pipe were used for the first time in scientific ocean drilling during Integrated Ocean Drilling Program (IODP) Expeditions 327 and 336. Here, we summarize the carbon, nitrogen, and iron leaching characteristics of the various materials used and considered for the observatory construction, as these substrates may potentially induce or inhibit in situ microbial growth. We also report on the fluorescence properties of several dopes and sealants used in observatory construction, as these may interfere with DNA-based fluorescence observations on observatory microbial colonization experiments.

\section{Introduction}

Subseafloor borehole observatories (CORKs) have been used successfully for several decades to study hydrological and geochemical dynamics in deep oceanic crust (Becker and Davis, 2005; Fisher et al., 2011). Essentially, CORKs are instrumented experimental wells deployed in boreholes created through ocean drilling that consist of a series of pipes extending below the seafloor that house the instruments and sensors, seals at the seafloor and various depths to isolate intervals, and a wellhead protruding above the seafloor. Traditionally, CORKs were constructed from "low alloy" steel pipe. While this is relatively inconsequential for hydrological experiments, the corrosion of steel has potential undesirable effects for microbiological and biogeochemical studies. For example, corrosion of steel pipe leads to leaching of iron and other metals into the environment (Wheat et al., 2004), which changes the biogeochemistry of the crustal environment, potentially masking in situ iron cycling within the basement basalts.

Within the last decade, several CORKs on the Juan de Fuca Ridge flank in the northeastern Pacific Ocean have been instrumented with experiments for studying the microbiology of oceanic crust. These experiments include the use of nonreactive coated tubes for pumping fluids from basement formations as well as the deployment of colonization experiments within the boreholes (Cowen et al., 2012; Fisher et al., 2011, 2005; Orcutt et al., 2011; Smith et al., 2011). During Integrated Ocean Drilling Program (IODP) Expedition 327 to the Juan de Fuca Ridge flank, several new CORKs that were installed featured steel pipe that had been coated with epoxy resins to limit corrosion (Fisher et al., 2011). The decision to 
use coated steel was based, in part, on a series of experiments conducted to evaluate the leaching characteristics of alternative observatory construction materials (Orcutt et al., 2010). In particular, these experiments evaluated the release of carbon and nitrogen from various epoxy resins, as well as fiberglass pipe and other construction materials. Building on those experiences, during IODP Expedition 336 to the North Pond location on the western flank of the MidAtlantic Ridge, all borehole observatory materials placed with the formations of interest were composed of either epoxy-coated steel or fiberglass pipethe first time that this material has been used in scientific ocean drilling (Expedition 336 Scientists, 2012). Furthermore, new plastic centralizers and strapping bands were also used to reduce the amount of metal materials within the observatory zones.

Here, we summarize all of the available results regarding the release of carbon, nitrogen, and iron from these alternative construction materials. Some of these data have been presented elsewhere (Orcutt et al., 2010) and are reproduced here with permission. We also discuss the fluorescence of various greases and lubricants used during observatory construction, as background fluorescence may obfuscate efforts to evaluate microbial abundances based on fluorescence of cells marked with DNA stains (Orcutt et al., 2011).

\section{Materials and methods Construction of Expedition 336 CORK observatories}

CORK assembly during Expedition 336 followed the basic plans used during previous expeditions (Fisher et al., 2011). For a more detailed outline of each observatory deployed during Expedition 336, see the operations for this expedition (Expedition 336 Scientists, 2012). In general, the lowermost portion of the CORK installation consisted of coated and perforated $63 / 4$ inch outside diameter (OD) steel drill collars, which were coated on the outside and inside with Xylan (polytetrafluoroethylene [PTFE] fluoropolymer). During installation, tool marks on the exterior of the drill collars were covered with a coat of freshly prepared Alocit 28 epoxy paint (Fig. F1). Perforated steel pipe (51/2 inch diameter) was connected to the drill collars and was the location of the miniscreens and OsmoSampler instruments (described in Edwards et al., 2012). This section of perforated casing was precoated with either Tuboscope TK-34XT on the inside and outside or TK-34XT on the inside with Amerlock epoxy paint (white) on the outside. Tool marks were coated with Alocit 28 epoxy paint. Slotted (vertical slots of 0.020 inches width $\times 2.75$ inches length, $5 \%$ open area) and unslotted $4 \frac{1}{2}$ inch OD fiberglass casing was made of an aromatic amine curing formulation. A similar aromatic amine-cured fiberglass from STAR FiberGlassSystems was previously tested for carbon and nitrogen leaching characteristics (Orcutt et al., 2010). Combination swellable and inflatable rubber packers were used to isolate hydrologic zones of interest. The combination packer swellable material was Freecap/Xtracap that had also been examined previously for carbon and nitrogen leaching (Orcutt et al., 2010). Any exposed steel below the packer element (combo packer mandrel, landing seat, etc.) was coated with Amerlock epoxy paint during deployment in the moonpool on the R/V JOIDES Resolution. On the exterior of the casing, plastic-coated umbilical lines were held in place with Nylon 11 Smartbands and either plastic (acetal polyoxymethylene) centralizers (for fiberglass casing) or Xylan-coated steel centralizers (for coated steel casing). Steel-to-steel connections were lubricated and sealed with Loctite 30561 thread sealant with PTFE. Fiberglass-to-steel connections were lubricated and sealed with APT 3 thread sealant. Fiberglass-to-fiberglass connections were lubricated and sealed with TF-15 grease (a black reprocessed PTFE fluorocarbon resin with molybdenum disulfide).

\section{Leaching experiments}

To examine the carbon and nitrogen release from the alternative borehole observatory materials used or considered during Expedition 336, samples of the materials were incubated in sterile seawater (Sigma S9148) for a period of up to 1 month at various temperatures. The temperatures used $\left(4^{\circ} \mathrm{C}\right.$, room temperature $\left[20-22^{\circ} \mathrm{C}\right]$, and/or $60^{\circ} \mathrm{C}$ ) were chosen to approximate the range that borehole observatories would experience at either the Juan de Fuca Ridge flank (warmer) or North Pond (cooler) locations. The materials that were tested include the following:

- Tuboscope Coat TK-2 (liquid phenolic-based coating, TAM International, Houston, Texas, USA)

- Tuboscope Coat TK-34XT (modified epoxy-phenolic liquid coating, TAM International)

- Tuboscope Coat TK-69 (epoxy-modified phenolic liquid coating, TAM International)

- Tuboscope Coat TK-805 (phenolic Novolac [powder] coating, TAM International)

- Amerlock 400 epoxy paint (Ameron International)

- Alocit 28 epoxy paint (15 standard grey RAL7004 and hardener, A\&E Systems)

- Xylan coat (a PTFE fluoropolymer, Whitford)

- Aliphatic-cured epoxy fiberglass (STAR FiberGlassSystems, San Antonio, Texas, USA) 
- Anhydride-cured epoxy fiberglass (STAR FiberGlassSystems)

- Aromatic amine-cured epoxy fiberglass (STAR FiberGlassSystems)

- Standard inflatable rubber packer polymer (TAM International)

- Freecap FSC-11 swellable packer polymer (TAM International)

- Bestolife $60 \%$ lead-base dope (60\% pure metallic lead in a petroleum grease mixture with nonmetal additives; Bestolife Corporation, Dallas, Texas, USA)

- Bestolife ZN 50 dope (50\% zinc in a petroleum grease mixture; Bestolife Corporation)

- Bestolife Eco-Sil dope (silicone and titanium oxide mixture; Bestolife Corporation)

- APT 3 thread sealant (APT Sealant, Wichita, Kansas, USA)

- Loctite 30561 thread sealant with PTFE (Teflon, Loctite Corporation)

- Dow Corning Compound 111 valve lubricant and sealant (a polydimethlysiloxane, Dow Corning Corporation)

- TF-15 grease (a black reprocessed PTFE fluorocarbon resin with molybdenum disulfide, Jet-Lube of Canada Ltd.)

Leaching experiments for the TAM International Tuboscope-coated steel products and packer materials were conducted in acid-washed and baked $\left(450^{\circ} \mathrm{C}\right.$, to remove organics) $60 \mathrm{~mL}$ glass I-Chem vials with Teflon-lined screw caps (Fig. F2). Prior to incubation, samples were washed in dilute detergent and rinsed thoroughly with deionized water, followed by rinsing in 100\% ethanol and air-drying. Coated steel samples were incubated in $35 \mathrm{~mL}$ of sterile seawater, which covered the lower $3^{1 / 2}$ inches of the piece and avoided the end that had an internal threaded hole into the steel. Strips of the packer material were cut $\left(1 \frac{1 / 4}{\mathrm{~cm}}\right.$ wide $\times 10 \mathrm{~cm}$ long) to fit into the incubation vessels (Fig. F2B). Samples were briefly cleaned as described above, with the exception of the Freecap FSC-11 packer material, which immediately soaked up any liquid upon contact. Materials were incubated at temperature for $1 \mathrm{~h}$ and then transferred with sterile tools to a fresh vial prepared at the appropriate temperature. This procedure was repeated after 1 day, 1 week, and 1 month of incubation.

Leaching experiments with the Amerlock 400 epoxy paint were conducted in two different ways. In the first instance, steel coupons $\left(60 \mathrm{~cm}^{2}\right.$ surface area) were coated with Amerlock applied by the vendor with heating. The coated coupons were rinsed as described above, then incubated in $50 \mathrm{~mL}$ of sterile seawater in large-mouth glass jars (acid-washed and baked) sealed with a plastic lid (care was taken to avoid contact of the seawater with the lid) (Fig. F3). These samples were also incubated for periods of $1 \mathrm{~h}$, 1 day, 1 week, and 1 month as described above. Leaching tests with the Xylan coating were performed in a similar manner. In the second instance, fresh Amerlock epoxy paint (roughly $500 \mu \mathrm{L}$ or $0.2 \mathrm{~g}$ material) was injected into the base of $8 \mathrm{~mL}$ glass vials (acid-washed and baked) with plastic screw cap lids and allowed to harden overnight (Fig. F2C). Subsequently, $5 \mathrm{~mL}$ of sterile seawater was added to the vial for the incubation for 1 day and 1 month time periods. Leaching experiments with the Alocit $28 \mathrm{ep}-$ oxy paint, sealants (i.e., TF-15 grease, Loctite 30561, APT 3, and Dow Corning Compound 111), and dopes (i.e., 60\% lead-base, ZN 50, and Eco-Sil) were conducted in a similar manner, although the TF-15 grease, APT 3 thread sealant, and dopes were smeared on the inside of the vial instead of deposited at the bottom (Fig. F2C). Each dope/temperature condition was run in duplicate, whereas the grease and sealant experiments were run in triplicate.

Fiberglass leaching experiments were conducted on small pieces $\left(\sim 4 \mathrm{~cm}^{2}\right.$ surface area) of pipe that were cut using an ultralow-speed diamond wafering blade rock saw (Buehler) with deionized water as a cutting fluid (Fig. F2D, F2E). Pieces were washed in dilute detergent and rinsed thoroughly with deionized water, followed by rinsing in 100\% ethanol and airdrying. Pieces were incubated in $14 \mathrm{~mL}$ of sterile seawater (as above) in acid-washed $20 \mathrm{~mL}$ glass vials with Teflon-lined screw caps (taking care to keep incubation fluids from contacting the lid as much as possible) for 1 month.

In all experimental incubation set ups, "control" samples that did not contain sample material were incubated and sampled in parallel to correct for any changes not due to material leaching. At the end of all incubations, sample fluid was frozen until subsequent dissolved organic carbon (DOC) and total dissolved nitrogen (TDN) analysis. DOC and TDN concentrations were measured in the Joye Geochemistry Analytical Laboratory at the University of Georgia (USA) according to published protocols (Weston and Joye, 2005). Briefly, $10 \mathrm{~mL}$ of fluid from the leaching experiments was transferred into acid-washed, combusted autosampler vials. DOC and TDN concentrations were determined on a Shimadzu TOC-V with an ASI-V autosampler and TNM-1 total nitrogen unit. The lower limits of detection were roughly 1 and 0.1 parts per million for DOC and TDN, respectively. Results for the fiberglass and Tuboscope product leaching experiments have been reported previously (Orcutt et al., 2010) and are reproduced here with permission. 


\section{Fluorescence tests with pipe dopes and sealants}

To evaluate the fluorescence properties of the pipe dopes and sealants used in observatory construction, select samples were mixed with fluorescent dyes commonly used for DNA-based assays (propidium iodide and SYTO 9 nucleic acid dyes, Invitrogen) and evaluated by epifluorescence microscopy. Briefly, either a smear of dope was placed directly on a glass slide and covered with $10 \mu \mathrm{L}$ of 1:500 diluted dye, or $0.1 \mathrm{~g}$ dope was first mixed with $1 \mathrm{~mL}$ of double deionized water, sonicated in a bath for $10 \mathrm{~min}$ (FS20 sonicator, Fisher Scientific), mixed with $1 \mathrm{~mL}$ of 1:500 diluted dye, and then filtered through a $0.2 \mu \mathrm{m}$ mesh black Nucleopore polycarbonate membrane filter (Whatman) supported by a $0.8 \mu \mathrm{m}$ mesh AAWP membrane filter (Millipore). Fluorescence was then evaluated using either an Axiostar Plus epifluorescent microscope (Carl Zeiss Microscopy) equipped with filter set $38 \mathrm{HE}$ ( $470 \mathrm{~nm}$ centered excitation in a $40 \mathrm{~nm}$ window, $525 \mathrm{~nm}$ centered emission in a $50 \mathrm{~nm}$ window, and $495 \mathrm{~nm}$ beam splitter) or a TCS SPE confocal microscope (Leica Microsystems) using a $488 \mathrm{~nm}$ solid-state laser for excitation and emission wavelengths of 495-550 nm for SYTO 9 and 555-700 nm for propidium iodide. The compounds tested included dope commonly used on drill collars on the JOIDES Resolution (Bestolife 60\% lead-base dope, Loctite 30561, and Dow Corning Compound 111).

\section{Results \\ Visible changes in materials during incubation}

Whereas most of the materials tested did not noticeably change in appearance over the course of the incubation periods and the seawater incubation solution did not alter in a visible way, some materials did show marked changes. The swellable packer polymer (Freecap) was observed to very quickly initiate swelling upon contact with solution (Fig. F2B). By the end of the incubation period (1 month), the incubation solution had acquired a noticeable bronzy hue (data not shown). Of all of the coated steel samples, the Xylan-coated coupons were the only ones that showed any rust discoloration. As evident in Figure F3, the formation of rust was quite extensive in the Xylan materials incubated at high temperatures, although rust was also evident in limited quantities in the $4^{\circ} \mathrm{C}$ incubated coupons.

\section{Carbon leaching from borehole materials}

In all of the experiments conducted, the rate of carbon leaching from the materials declined over time
(Table T1). The carbon leaching rates revealed temperature sensitivity, with higher rates at higher temperatures (i.e., rates at $60^{\circ} \mathrm{C}$ were roughly an order of magnitude higher than at $4^{\circ} \mathrm{C}$ in several experiments). Among the baked-on resin coatings on steel coupons, the Tuboscope TK-805 product had the lowest overall carbon leaching rates (e.g., $0.4 \mathrm{nmol} \mathrm{C} / \mathrm{cm}^{2} / \mathrm{d}$ after 1 month), with the other Tuboscope products leaching carbon at higher but similar rates and the Amerlock epoxy paint having the highest leaching rate over time at $60^{\circ} \mathrm{C}$. The higher leaching rate of Amerlock may have been influenced by the higher comparative surface area of the Amerlock-coated coupons (Fig. F2) as compared to the Tuboscope samples (Fig. F3); however, the Xylan-coated steel coupons had a similar surface area as the Amerlock-coated coupons, and the Xylan material had a lower carbon leaching rate. The carbon leaching rates from the dried wetpaint samples of the Amerlock and Alocit 28 resins also had similar leaching rates. Among the fiberglass samples tested, the aliphatic-cured epoxy fiberglass had the highest carbon leaching rates $(\sim 100 \mathrm{nmol}$ $\mathrm{C} / \mathrm{cm}^{2} / \mathrm{d}$ after 1 month), while the carbon leaching rates from the other two fiberglass types (anhydrideand aromatic amine-cured) were lower by about an order of magnitude. The Freecap swellable packer material had some of the highest carbon leaching

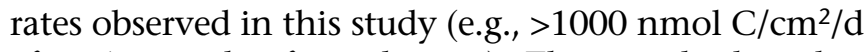
after 1 month of incubation). The standard packer material also had high carbon leaching rates in comparison to the coated steel and fiberglass materials, but the leaching rates were roughly an order of magnitude lower than those of the swellable packer material. The Eco-Sil dope, which was not used in the Expedition 327 or 336 CORKs, had the highest carbon leaching rate of all of the materials tested (>1000 $\mathrm{nmol} \mathrm{C} / \mathrm{cm}^{2} / \mathrm{d}$ after 1 month). The carbon leaching rates from the hydrocarbon-based Bestolife dopes were also rather high $\left(>100 \mathrm{nmol} \mathrm{C} / \mathrm{cm}^{2} / \mathrm{d}\right)$ even after 1 month of incubation. Interestingly, the TF-15 grease has lower carbon leaching rates than the Loctite 30561 and APT 3 sealants tested.

\section{Nitrogen leaching from borehole materials}

The nitrogen leaching rates were also higher at higher temperatures and decreased over time (Table T2). Among the baked-on resin coatings, the compounds Amerlock, Xylan, and Tuboscope TK-2 had the highest nitrogen leaching rates, which were at least an order of magnitude higher than the leaching rates of the other baked-on resins. The freshly dried Amerlock 400 and Alocit 28 resins leached more nitrogen than the baked-on coatings. The aliphaticcured epoxy fiberglass had the highest nitrogen leaching rates of the fiberglass samples, and the 
aromatic amine-cured epoxy fiberglass had the lowest rates. The drill pipe/Bestolife ZN 50 dope had lower overall nitrogen leaching rates than the drill collar/Bestolife $60 \%$ lead-base dope, and there was no detectable nitrogen from any of the Eco-Sil incubations. The APT 3 sealant had the highest nitrogen leaching rates observed in these experiments, with rates $>100 \mathrm{nmol} / \mathrm{g} / \mathrm{d}$ after $1 \mathrm{month}$ of incubation.

\section{Fluorescence characteristics of dopes and sealants}

The SYTO 9 and propidium iodide nucleic acid stains reacted with the dopes and sealants tested (Fig. F4). The SYTO 9 stain reacted with Dow Corning Compound 111 when directly applied (Fig. F4A). When this sealant was mixed with water and disrupted by bath sonication, the solution became cloudy due to the formation of small particles. These particles also reacted with SYTO 9 (Fig. F4B), and the sizes of the particles fell within the range of average prokaryotic cell sizes. These particles did not react with propidium iodide dye (data not shown). When SYTO 9 was directly applied to Loctite 30561 smeared on a glass slide, the material gained significant fluorescence (Fig. F4C). By contrast, when Loctite 30561 was mixed with water and sonicated, the high viscosity and hydrophobicity of this material did not yield prokaryote-sized fluorescent particles (Fig. F4D). Similar behaviors were also observed with the propidium iodide (data not shown). Thus, the likelihood of Loctite 30561 interfering with DNA-based cell staining techniques should be minimal. The SYTO 9 stain also reacted with the Bestolife $60 \%$ lead-base dope, as evidenced by the observation of fluorescent particles that are in the range of sizes observed for average prokaryotic cells (Fig. F4E).

\section{Discussion}

In an effort to minimize perturbation of subsurface borehole environments for microbiology-related experimentation and observation, several alternative materials (to low-alloy steel) for observatory casing were examined for suitable properties. These examinations began in 2008, prior to Expedition 327, to guide the selection of materials to be used in CORK observatories. Early published results from leaching experiments with fiberglass and several resin coatings suggested that fiberglass had the best (i.e., lowest) rates of carbon and nitrogen leaching and that all materials had improved iron leaching characteristics as compared to bare steel pipe (Orcutt et al., 2010). Due to budgetary, risk, and time restraints, Expedition 327 CORK steel materials were coated with Amerlock 400 and TK-34XT resins, and fiberglass was not used (Fisher et al., 2011). In contrast, an aromatic amine-cured fiberglass product was used in Expedition 336 CORK observatories in addition to Amerlock-, Xylan-, and TK-34XT-coated steel pipe (Expedition 336 Scientists, 2012). It is expected that these new CORK observatories should have significantly improved experimental conditions for microbiological investigations, especially in relation to the leaching of iron in the borehole environment, although Xylan-coated steel does seem to allow for a significant amount of rust to be released into surrounding fluids. Further studies are necessary to examine the properties, fate, and impact of the low levels of organic carbon and nitrogen compounds expected to leach from the alternative materials used in the Expedition 336 observatories. It should be cautioned that, although these experiments were conducted at the higher temperatures expected in some crustal environments like the Juan de Fuca Ridge flank, we did not replicate the reducing (i.e., anoxic) fluid conditions present there; thus, it is unknown how these materials behave under reducing conditions.

The observation of significant reaction of common nucleic acid stains with the dopes used in observatory construction suggests caution may be necessary in interpretation of borehole and crustal samples investigated for cell density measurements based on microscopy. The nonspecific binding of nucleic acid stains to noncellular material has been observed previously; for example, in the binding of SYBR Green I nucleic acid stain to the mineral stalks produced by iron oxidizing bacteria in borehole colonization experiments (Orcutt et al., 2011) and in the binding of SYBR Green I to debris in sediments (Morono et al., 2009). In the past, some researchers have described the presence of DNA in "microtubes" in crustal thin sections based on nucleic acid staining (e.g., Banerjee and Muehlenbachs, 2003), and have used such observations as evidence for microbial life in these microtubes. We suggest that caution must be used in such extrapolations, considering that our results show the common nonspecific binding of DNA stains to dopes and other materials that would be used during the drilling process used to collect the hard rock samples.

\section{Acknowledgments}

The authors would like to thank Tom Pettigrew, Kevin Grigar, and Bill Rhinehart for assistance in identifying and supplying materials for testing, Kim Hunter for analyzing samples, and Victoria Orphan for providing comments on this manuscript. This research was supported by the U.S. National Science 
Foundation Ocean Drilling Program (OCE-0737300, K.J. Edwards), the Gordon and Betty Moore Foundation (K.J. Edwards), the Danish National Research Foundation and the Max Planck Society (B.N. Orcutt), the Center for Dark Energy Biosphere Investigation Science and Technology Center (C-DEBI contribution Number 133), and the Integrated Ocean Drilling Program.

\section{References}

Banerjee, N.R., and Muehlenbachs, K., 2003. Tuff life: bioalteration in volcaniclastic rocks from the Ontong Java Plateau. Geochem., Geophys., Geosyst., 4:1037. doi:10.1029/2002GC000470

Becker, K., and Davis, E.E., 2005. A review of CORK designs and operations during the Ocean Drilling Program. In Fisher, A.T., Urabe, T., Klaus, A., and the Expedition 301 Scientists, Proc. IODP, 301: College Station, TX (Integrated Ocean Drilling Program Management International, Inc.). doi:10.2204/iodp.proc.301.104.2005

Cowen, J.P., Copson, D.A., Jolly, J., Hsieh, C.-C., Lin, H.-T., Glazer, B.T., and Wheat, C.G., 2012. Advanced instrument system for real-time and time-series microbial geochemical sampling of the deep (basaltic) crustal biosphere. Deep-Sea Res., Part I, 61:43-56. doi:10.1016/ j.dsr.2011.11.004

Edwards, K.J., Wheat, C.G., Orcutt, B.N., Hulme, S., Becker, K., Jannasch, H., Haddad, A., Pettigrew, T., Rhinehart, W., Grigar, K., Bach, W., Kirkwood, W., and Klaus, A., 2012. Design and deployment of borehole observatories and experiments during IODP Expedition 336, MidAtlantic Ridge flank at North Pond. In Edwards, K.J., Bach, W., Klaus, A., and the Expedition 336 Scientists, Proc. IODP, 336: Tokyo (Integrated Ocean Drilling Program Management International, Inc.). doi:10.2204/ iodp.proc.336.109.2012

Expedition 336 Scientists, 2012. Mid-Atlantic Ridge microbiology: initiation of long-term coupled microbiological, geochemical, and hydrological experimentation within the seafloor at North Pond, western flank of the Mid-Atlantic Ridge. IODP Prel. Rept., 336. doi:10.2204/ iodp.pr.336.2012

Fisher, A.T., Wheat, C.G., Becker, K., Cowen, J., Orcutt, B., Hulme, S., Inderbitzen, K., Turner, A., Pettigrew, T.L., Davis, E.E., Jannasch, H., Grigar, K., Adudell, R., Meldrum, R., Macdonald, R., and Edwards, K., 2011. Design, deployment, and status of borehole observatory systems used for single-hole and cross-hole experi- ments, IODP Expedition 327, eastern flank of Juan de Fuca Ridge. In Fisher, A.T., Tsuji, T., Petronotis, K., and the Expedition 327 Scientists, Proc. IODP, 327: College Station, TX (Integrated Ocean Drilling Program Management International, Inc.). doi:10.2204/ iodp.proc.327.107.2011

Fisher, A.T., Wheat, C.G., Becker, K., Davis, E.E., Jannasch, H., Schroeder, D., Dixon, R., Pettigrew, T.L., Meldrum, R., MacDonald, R., Nielsen, M., Fisk, M., Cowen, J., Bach, W., and Edwards, K., 2005. Scientific and technical design and deployment of long-term subseafloor observatories for hydrogeologic and related experiments, IODP Expedition 301, eastern flank of Juan de Fuca Ridge. In Fisher, A.T., Urabe, T., Klaus, A., and the Expedition 301 Scientists, Proc. IODP, 301: College Station, TX (Integrated Ocean Drilling Program Management International, Inc.). doi:10.2204/iodp.proc.301.103.2005

Morono, Y., Terada, T., Masui, N., and Inagaki, F., 2009. Discriminative detection and enumeration of microbial life in marine subsurface sediments. ISME J., 3(5):503511. doi:10.1038/ismej.2009.1

Orcutt, B., Wheat, C.G., and Edwards, K.J., 2010. Subseafloor ocean crust microbial observatories: development of FLOCS (Flow-Through Osmo Colonization System) and evaluation of borehole construction materials. Geomicrobiol. J., 27(2):143-157. doi:10.1080/ 01490450903456772

Orcutt, B.N., Bach, W., Becker, K., Fisher, A.T., Hentscher, M., Toner, B.M., Wheat, C.G., and Edwards, K.J., 2011. Colonization of subsurface microbial observatories deployed in young ocean crust. ISME J., 5:692-703. doi:10.1038/ismej.2010.157

Smith, A., Popa, R., Fisk, M., Nielsen, M., Wheat, C.G., Jannasch, H.W., Fisher, A.T., Becker, K., Sievert, S.M., and Flores, G., 2011. In situ enrichment of ocean crust microbes on igneous minerals and glasses using an osmotic flow-through device. Geochem., Geophys., Geosyst., 12(6):Q06007. doi:10.1029/2010GC003424

Weston, N.B., and Joye, S.B., 2005. Temperature-driven decoupling of key phases of organic matter degradation in marine sediments. Proc. Nat. Acad. Sci. U. S. A., 102(47):17036-17040. doi:10.1073/pnas.0508798102

Wheat, C.G., Jannasch, H.W., Kastner, M., Plant, J.N., DeCarlo, E.H., and Lebon, G., 2004. Venting formation fluids from deep-sea boreholes in a ridge flank setting: ODP Sites 1025 and 1026. Geochem., Geophys., Geosyst., 5(8):Q08007. doi:10.1029/2004GC000710

Publication: 16 November 2012 MS 336-108 
Figure F1. Coatings and sealants used during CORK casing during Expedition 336. A. Application of Alocit 28 paint on Amerlock- (exterior) and TK-34XT-coated (interior) drill collars. B. Application of Alocit 28 paint on Xylan-coated drill collars. C. Application of Amerlock epoxy paint to packer mandrel. D. Application of APT 3 sealant between fiberglass-to-steel connections. E. Cleaning of Xylan-coated drill collars with ethanol prior to application of Amerlock epoxy paint. Photo credits: (A, D, E) Bill Crawford/TAMU; (B, C) Geoff Wheat.
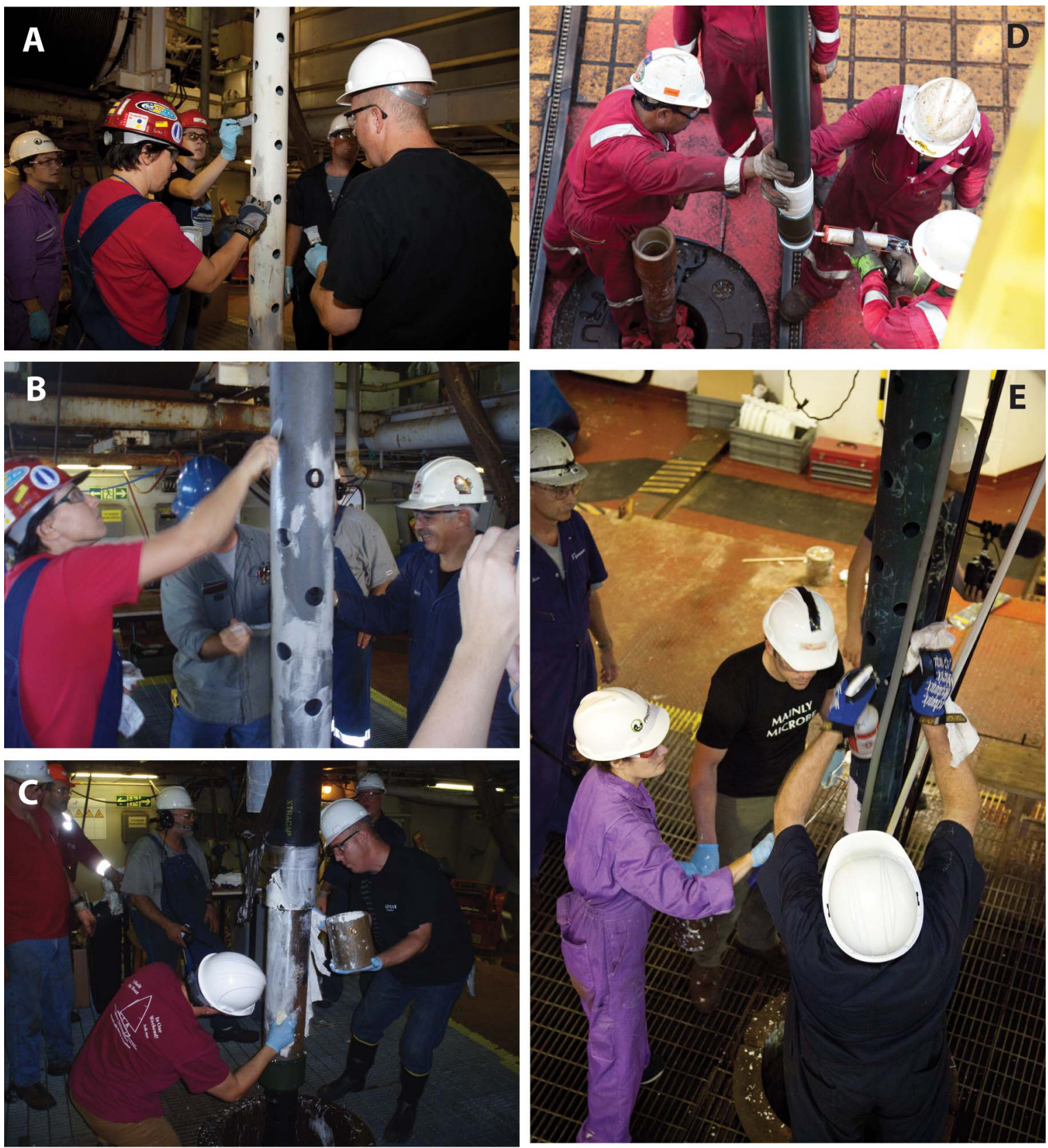
Figure F2. Various materials tested for carbon, nitrogen, and iron leaching in this study. A. Tuboscope coatings on steel plugs, from left to right: Coats TK-805, TK-2, TK-34XT, TK-69. B. Swatches of packer materials FSC11 (left) and standard (right). C. Dried plugs of Amerlock epoxy paint, Alocit 28 epoxy paint, TF-15 grease, Loctite 30561 thread sealant, and APT 3 thread sealant. D. Example of anhydride-cured epoxy fiberglass pipe. E. Representative pieces of fiberglass used in the incubations.

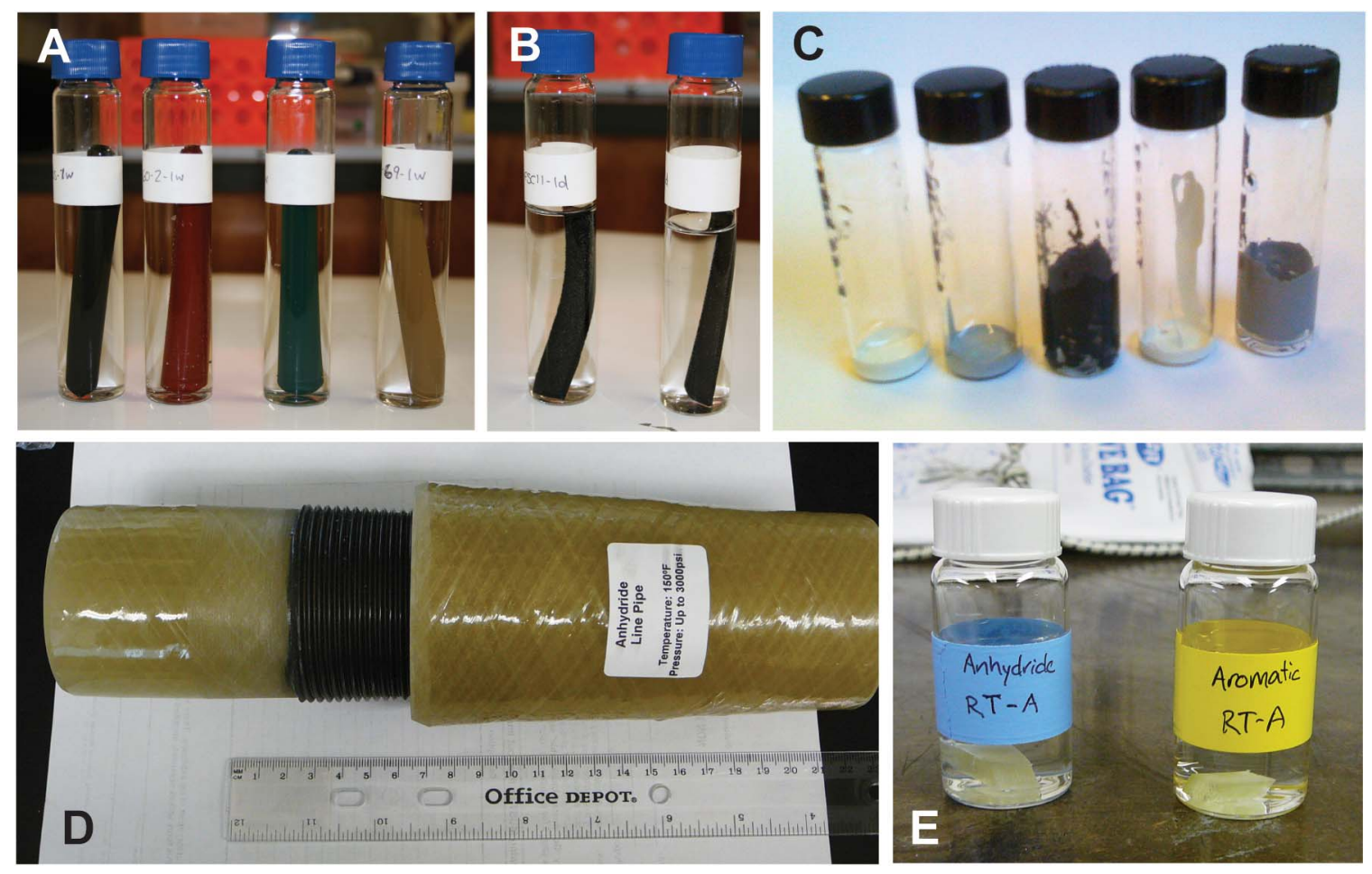


Figure F3. Comparison of Amerlock- and Xlyan-coated steel coupons after incubation in seawater for one month at different temperatures $\left(4^{\circ} \mathrm{C}\right.$, room temperature $[\mathrm{RT}]\left[20^{\circ}-22^{\circ} \mathrm{C}\right]$, and $\left.60^{\circ} \mathrm{C}\right)$. Upper panel shows the degree of rust discoloration of coupons, while lower panel shows rust discoloration in the Xylan seawater incubations. Each coupon is $5 \mathrm{~cm}$ in length.

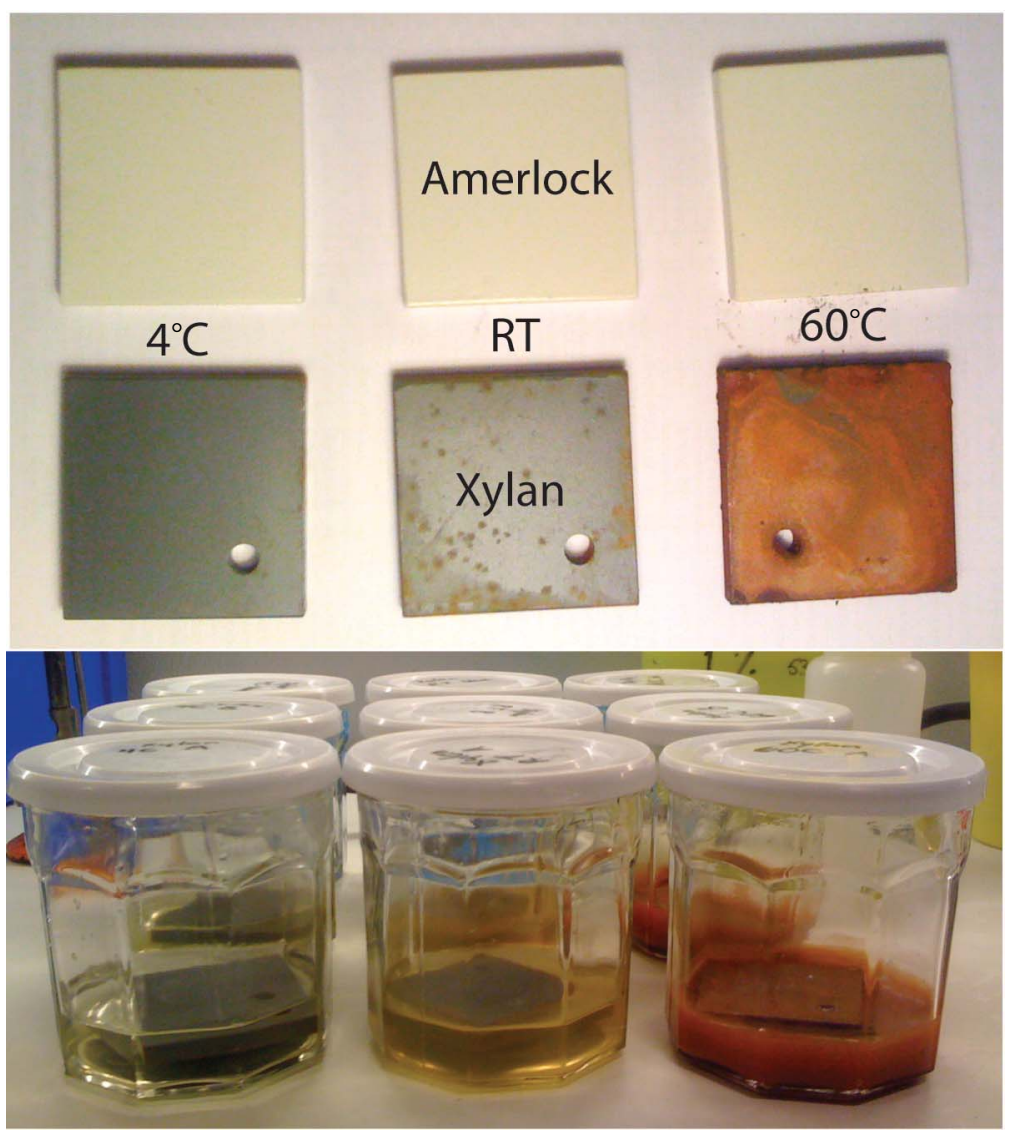


Figure F4. Green fluorescence of sealants and pipe dope used in borehole observatory construction, mixed with SYTO 9 stain. Fluorescence of Dow Corning Compound 111 (A) in a smear and (B) after sonication in water. Fluorescence of Loctite 30561 thread sealant (C) as a smear and (D) after sonication in water. E. Fluorescence of Bestolife $60 \%$ lead-base dope in a smear. Scale bars $=10 \mu \mathrm{m}$.
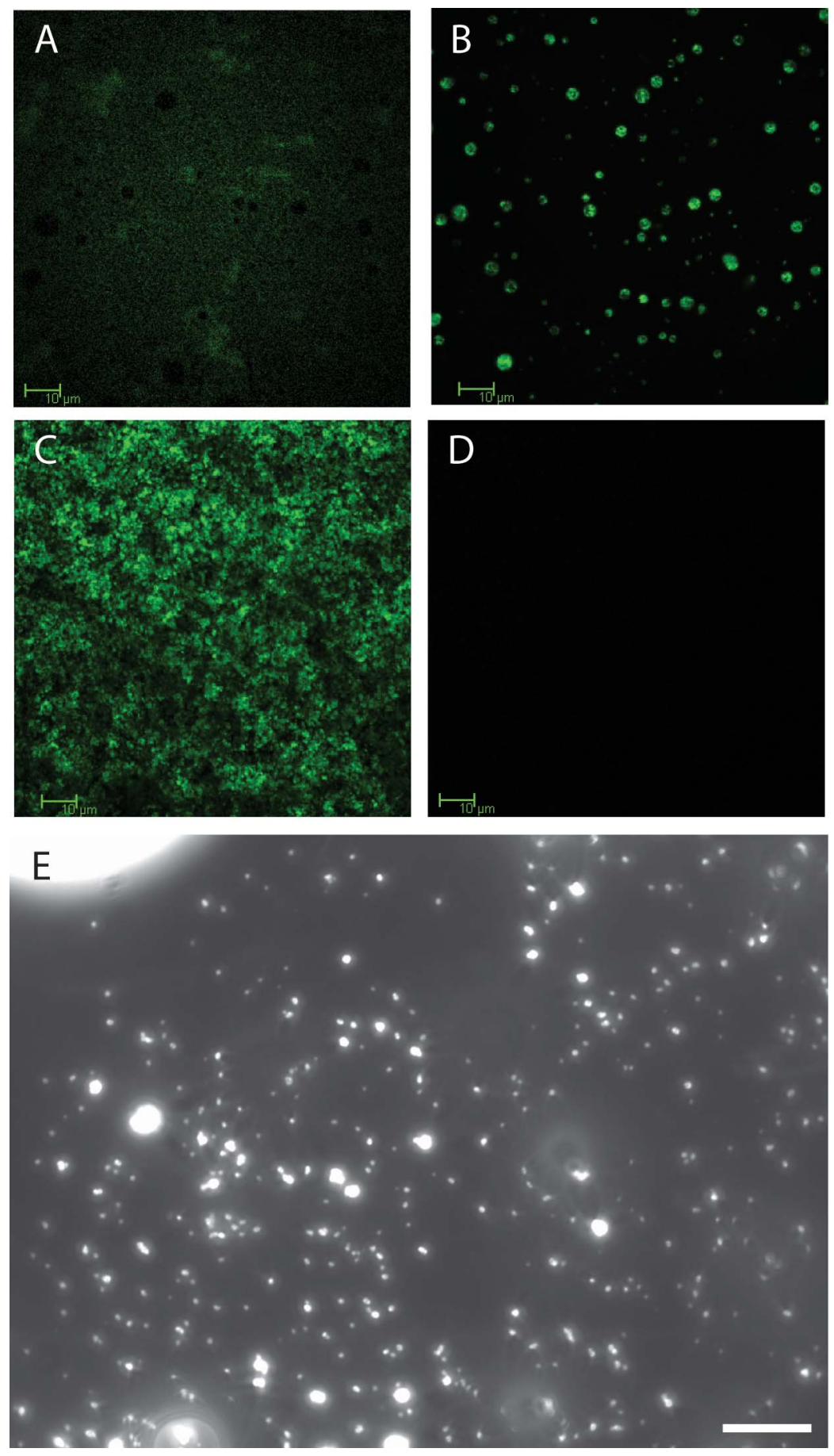
Table T1. Summary of carbon leaching rates from borehole and CORK materials incubated in seawater at three different temperatures $\left(4^{\circ} \mathrm{C}\right.$, room temperature $\sim 22^{\circ} \mathrm{C}$, and $\left.60^{\circ} \mathrm{C}\right)$.

\begin{tabular}{|c|c|c|c|c|c|c|c|c|c|c|c|c|}
\hline \multirow{2}{*}{$\begin{array}{l}\text { Material } \\
\text { (unit) }\end{array}$} & \multicolumn{4}{|c|}{$4^{\circ} \mathrm{C}$} & \multicolumn{4}{|c|}{ Room temperature } & \multicolumn{4}{|c|}{$60^{\circ} \mathrm{C}$} \\
\hline & $1 \mathrm{~h}$ & 1 day & 1 week & 1 month & $1 \mathrm{~h}$ & 1 day & 1 week & 1 month & $1 \mathrm{~h}$ & 1 day & 1 week & 1 month \\
\hline Coat TK-2 $\left(\mathrm{nmol} / \mathrm{cm}^{2} / \mathrm{d}\right)$ & $1 \mathrm{E}+05$ & $6 \mathrm{E}+02$ & $3 \mathrm{E}+00$ & $8 \mathrm{E}-01$ & - & - & - & - & $4 \mathrm{E}+04$ & $1 \mathrm{E}+03$ & $6 \mathrm{E}+01$ & $5 \mathrm{E}+01$ \\
\hline Coat TK-34XT $\left(\mathrm{nmol} / \mathrm{cm}^{2} / \mathrm{d}\right)$ & $1 \mathrm{E}+05$ & $1 \mathrm{E}+03$ & $2 \mathrm{E}+00$ & $7 \mathrm{E}-01$ & - & - & - & - & $3 \mathrm{E}+04$ & $2 \mathrm{E}+03$ & $3 \mathrm{E}+01$ & $7 \mathrm{E}+00$ \\
\hline Coat TK-69 $\left(\mathrm{nmol} / \mathrm{cm}^{2} / \mathrm{d}\right)$ & $1 \mathrm{E}+05$ & $4 \mathrm{E}+02$ & $3 \mathrm{E}+00$ & $1 \mathrm{E}+00$ & - & - & - & - & $3 \mathrm{E}+04$ & $6 \mathrm{E}+02$ & $4 \mathrm{E}+01$ & $8 \mathrm{E}+00$ \\
\hline Coat TK-805 $\left(\mathrm{nmol} / \mathrm{cm}^{2} / \mathrm{d}\right)$ & $2 \mathrm{E}+03$ & $2 \mathrm{E}+01$ & $3 \mathrm{E}+00$ & $4 \mathrm{E}-01$ & - & - & - & - & $3 E+03$ & $1 \mathrm{E}+02$ & $1 \mathrm{E}+01$ & $3 \mathrm{E}+00$ \\
\hline Coat Xylan $\left(\mathrm{nmol} / \mathrm{cm}^{2} / \mathrm{d}\right)$ & - & $1 \mathrm{E}+01$ & $4 \mathrm{E}+00$ & $5 \mathrm{E}+00$ & - & $7 E+00$ & $3 \mathrm{E}+00$ & $5 \mathrm{E}+00$ & - & $6 \mathrm{E}+02$ & $2 \mathrm{E}+02$ & $6 \mathrm{E}+01$ \\
\hline Coat Amerlock1 $\left(\mathrm{nmol} / \mathrm{cm}^{2} / \mathrm{d}\right)$ & $2 \mathrm{E}+04$ & $3 \mathrm{E}+02$ & $7 \mathrm{E}+00$ & $1 \mathrm{E}+00$ & $2 \mathrm{E}+04$ & $4 \mathrm{E}+02$ & $2 \mathrm{E}+02$ & $9 \mathrm{E}+01$ & $6 \mathrm{E}+04$ & $1 \mathrm{E}+04$ & $2 \mathrm{E}+03$ & $3 \mathrm{E}+02$ \\
\hline Coat Amerlock2 $(\mu \mathrm{mol} / \mathrm{g} / \mathrm{d})$ & - & $8 \mathrm{E}+01$ & - & $2 \mathrm{E}+01$ & - & $2 \mathrm{E}+02$ & - & $3 \mathrm{E}+01$ & - & $8 \mathrm{E}+02$ & - & $2 \mathrm{E}+01$ \\
\hline Coat Alocit $28(\mu \mathrm{mol} / \mathrm{g} / \mathrm{d})$ & - & $2 \mathrm{E}+00$ & - & $1 \mathrm{E}-01$ & - & $8 \mathrm{E}+00$ & - & $5 \mathrm{E}-01$ & - & $4 \mathrm{E}+02$ & - & $2 \mathrm{E}+01$ \\
\hline FG anhydride $\left(\mathrm{nmol} / \mathrm{cm}^{2} / \mathrm{d}\right)$ & - & - & - & $4 \mathrm{E}+00$ & - & - & - & $4 \mathrm{E}+00$ & - & - & - & $3 \mathrm{E}+01$ \\
\hline FG aromatic amine $\left(\mathrm{nmol} / \mathrm{cm}^{2} / \mathrm{d}\right)$ & - & - & - & $6 \mathrm{E}+00$ & - & - & - & $6 \mathrm{E}+00$ & - & - & - & $2 \mathrm{E}+01$ \\
\hline FG aliphatic $\left(\mathrm{nmol} / \mathrm{cm}^{2} / \mathrm{d}\right)$ & - & - & - & $2 \mathrm{E}+02$ & - & - & - & $6 \mathrm{E}+01$ & - & - & - & $3 \mathrm{E}+02$ \\
\hline Pack standard $\left(\mathrm{nmol} / \mathrm{cm}^{2} / \mathrm{d}\right)$ & $5 E+03$ & $9 \mathrm{E}+01$ & - & - & - & - & - & - & $1 \mathrm{E}+04$ & $2 \mathrm{E}+03$ & $6 \mathrm{E}+02$ & $1 \mathrm{E}+02$ \\
\hline Pack FSC-11 $\left(\mathrm{nmol} / \mathrm{cm}^{2} / \mathrm{d}\right)$ & $2 \mathrm{E}+05$ & $1 \mathrm{E}+04$ & $4 \mathrm{E}+03$ & $1 \mathrm{E}+03$ & - & - & - & - & $4 \mathrm{E}+05$ & $3 \mathrm{E}+04$ & $6 \mathrm{E}+03$ & $2 \mathrm{E}+03$ \\
\hline Bestolife $60 \%$ lead-base dope $\left(\mathrm{nmol} / \mathrm{cm}^{2} / \mathrm{d}\right)$ & - & $3 \mathrm{E}+03$ & $6 \mathrm{E}+02$ & $2 \mathrm{E}+02$ & - & $4 \mathrm{E}+03$ & $5 \mathrm{E}+02$ & $1 \mathrm{E}+02$ & - & $6 \mathrm{E}+03$ & $9 \mathrm{E}+02$ & $4 \mathrm{E}+02$ \\
\hline Bestolife ZN 50 dope $\left(\mathrm{nmol} / \mathrm{cm}^{2} / \mathrm{d}\right)$ & - & $2 \mathrm{E}+03$ & $2 \mathrm{E}+02$ & $8 \mathrm{E}+01$ & - & $4 \mathrm{E}+03$ & $5 \mathrm{E}+02$ & $1 \mathrm{E}+02$ & - & $8 \mathrm{E}+03$ & $9 \mathrm{E}+03$ & $6 \mathrm{E}+03$ \\
\hline Eco-Sil dope $\left(\mathrm{nmol} / \mathrm{cm}^{2} / \mathrm{d}\right)$ & $4 \mathrm{E}+04$ & $5 \mathrm{E}+03$ & $2 \mathrm{E}+03$ & $1 \mathrm{E}+03$ & $6 \mathrm{E}+04$ & $1 \mathrm{E}+04$ & $6 \mathrm{E}+03$ & $4 \mathrm{E}+03$ & $2 \mathrm{E}+05$ & $7 \mathrm{E}+04$ & $4 \mathrm{E}+04$ & $1 \mathrm{E}+04$ \\
\hline TF-15 grease $(\mu \mathrm{mol} / \mathrm{g} / \mathrm{d})$ & - & $3 \mathrm{E}+01$ & - & $2 \mathrm{E}+00$ & - & $4 \mathrm{E}+01$ & - & $2 \mathrm{E}+00$ & - & $2 \mathrm{E}+02$ & - & $2 \mathrm{E}+01$ \\
\hline Loctite sealant $(\mu \mathrm{mol} / \mathrm{g} / \mathrm{d})$ & - & $6 \mathrm{E}+02$ & - & $6 \mathrm{E}+01$ & - & $9 \mathrm{E}+02$ & - & $2 \mathrm{E}+01$ & - & $3 \mathrm{E}+03$ & - & $9 \mathrm{E}+00$ \\
\hline APT 3 sealant $(\mu \mathrm{mol} / \mathrm{g} / \mathrm{d})$ & - & $8 \mathrm{E}+02$ & - & $3 \mathrm{E}+01$ & - & $1 \mathrm{E}+03$ & - & $4 \mathrm{E}+01$ & - & $2 \mathrm{E}+03$ & - & $1 \mathrm{E}+02$ \\
\hline
\end{tabular}

Leaching rates expressed as nmol $\mathrm{C}$ leached per $\mathrm{cm}^{2}$ (surface area) per day or mmol C leached per gram material per day. $-=$ data not available.

Table T2. Summary of nitrogen leaching rates from borehole and CORK materials incubated in seawater at three different temperatures $\left(4^{\circ} \mathrm{C}\right.$, room temperature $\sim 22^{\circ} \mathrm{C}$, and $\left.60^{\circ} \mathrm{C}\right)$.

\begin{tabular}{|c|c|c|c|c|c|c|c|c|c|c|c|c|}
\hline \multirow{2}{*}{$\begin{array}{l}\text { Material } \\
\text { (unit) }\end{array}$} & \multicolumn{4}{|c|}{$4^{\circ} \mathrm{C}$} & \multicolumn{4}{|c|}{ Room temperature } & \multicolumn{4}{|c|}{$60^{\circ} \mathrm{C}$} \\
\hline & $1 \mathrm{~h}$ & 1 day & 1 week & 1 month & $1 \mathrm{~h}$ & 1 day & 1 week & 1 month & $1 \mathrm{~h}$ & 1 day & 1 week & 1 month \\
\hline Coat TK-2 (nmol/cm²/d) & $8 \mathrm{E}+01$ & $2 \mathrm{E}+00$ & $8 \mathrm{E}-01$ & $2 \mathrm{E}-01$ & - & - & - & - & $1 \mathrm{E}+02$ & $3 \mathrm{E}+01$ & $8 \mathrm{E}+00$ & $4 \mathrm{E}+00$ \\
\hline Coat TK-34XT $\left(\mathrm{nmol} / \mathrm{cm}^{2} / \mathrm{d}\right)$ & $1 \mathrm{E}+00$ & $5 \mathrm{E}-01$ & $2 \mathrm{E}-01$ & $6 \mathrm{E}-02$ & - & - & - & - & $6 \mathrm{E}+01$ & $6 \mathrm{E}+00$ & $8 \mathrm{E}-01$ & $2 \mathrm{E}-01$ \\
\hline Coat TK-69 $\left(\mathrm{nmol} / \mathrm{cm}^{2} / \mathrm{d}\right)$ & $1 \mathrm{E}+00$ & $1 \mathrm{E}-01$ & $1 \mathrm{E}-01$ & $7 \mathrm{E}-02$ & - & - & - & - & $2 \mathrm{E}+01$ & $4 \mathrm{E}+00$ & $5 \mathrm{E}-01$ & $1 \mathrm{E}-01$ \\
\hline Coat TK-805 $\left(\mathrm{nmol} / \mathrm{cm}^{2} / \mathrm{d}\right)$ & $2 \mathrm{E}+01$ & $9 \mathrm{E}-01$ & $3 \mathrm{E}-01$ & $1 \mathrm{E}-01$ & - & - & - & - & $8 \mathrm{E}+01$ & $5 \mathrm{E}+00$ & $5 \mathrm{E}-01$ & $6 \mathrm{E}-02$ \\
\hline Coat Xylan $\left(\mathrm{nmol} / \mathrm{cm}^{2} / \mathrm{d}\right)$ & - & $2 \mathrm{E}+00$ & $3 \mathrm{E}-01$ & $1 \mathrm{E}-01$ & - & $2 \mathrm{E}+00$ & $3 \mathrm{E}-01$ & 7E-01 & - & $9 \mathrm{E}+01$ & $2 \mathrm{E}+01$ & $1 \mathrm{E}+01$ \\
\hline Coat Amerlock1 $\left(\mathrm{nmol} / \mathrm{cm}^{2} / \mathrm{d}\right)$ & $4 \mathrm{E}+01$ & $2 \mathrm{E}+00$ & $2 \mathrm{E}-01$ & $1 \mathrm{E}+00$ & $2 \mathrm{E}+01$ & $1 \mathrm{E}+00$ & $2 \mathrm{E}-01$ & $3 \mathrm{E}-02$ & $5 \mathrm{E}+01$ & $7 \mathrm{E}+01$ & $3 \mathrm{E}+01$ & $8 \mathrm{E}+00$ \\
\hline Coat Amerlock2 (nmol/g/d) & - & $2 \mathrm{E}+01$ & - & $8 \mathrm{E}+00$ & - & $1 \mathrm{E}+02$ & - & $1 \mathrm{E}+01$ & - & $8 \mathrm{E}+02$ & - & $9 \mathrm{E}+01$ \\
\hline Coat Alocit $28(\mathrm{nmol} / \mathrm{g} / \mathrm{d})$ & - & $9 \mathrm{E}+00$ & - & $5 \mathrm{E}-01$ & - & $1 \mathrm{E}+01$ & - & $9 \mathrm{E}-01$ & - & $2 \mathrm{E}+02$ & - & $4 \mathrm{E}+01$ \\
\hline FG anhydride $\left(\mathrm{nmol} / \mathrm{cm}^{2} / \mathrm{d}\right)$ & - & - & - & $1 \mathrm{E}-03$ & - & - & - & $2 \mathrm{E}-01$ & - & - & - & $2 \mathrm{E}-01$ \\
\hline FG aromatic amine $\left(\mathrm{nmol} / \mathrm{cm}^{2} / \mathrm{d}\right)$ & - & - & - & $1 \mathrm{E}-04$ & - & - & - & $0 \mathrm{E}+00$ & - & - & - & $1 \mathrm{E}-03$ \\
\hline FG aliphatic $\left(\mathrm{nmol} / \mathrm{cm}^{2} / \mathrm{d}\right)$ & - & - & - & $7 \mathrm{E}-01$ & - & - & - & $2 \mathrm{E}+00$ & - & - & - & $3 \mathrm{E}+00$ \\
\hline Pack standard $\left(\mathrm{nmol} / \mathrm{cm}^{2} / \mathrm{d}\right)$ & $4 \mathrm{E}+01$ & $2 \mathrm{E}+00$ & & & - & - & - & - & $3 \mathrm{E}+02$ & $8 \mathrm{E}+01$ & $3 \mathrm{E}+01$ & $6 \mathrm{E}+00$ \\
\hline Pack FSC-11 $\left(\mathrm{nmol} / \mathrm{cm}^{2} / \mathrm{d}\right)$ & $7 \mathrm{E}+04$ & $8 \mathrm{E}+03$ & $2 \mathrm{E}+03$ & $2 \mathrm{E}+02$ & - & - & - & - & $9 \mathrm{E}+04$ & $2 \mathrm{E}+04$ & $2 \mathrm{E}+03$ & $4 \mathrm{E}+02$ \\
\hline Bestolife $60 \%$ lead-base dope $\left(\mathrm{nmol} / \mathrm{cm}^{2} / \mathrm{d}\right)$ & - & $6 \mathrm{E}+02$ & $2 \mathrm{E}+02$ & $5 \mathrm{E}+01$ & - & $1 \mathrm{E}+03$ & $2 \mathrm{E}+02$ & $4 \mathrm{E}+01$ & - & $3 \mathrm{E}+03$ & $1 \mathrm{E}+02$ & $3 \mathrm{E}+01$ \\
\hline Bestolife ZN 50 dope $\left(\mathrm{nmol} / \mathrm{cm}^{2} / \mathrm{d}\right)$ & - & $1 \mathrm{E}+02$ & $1 \mathrm{E}+01$ & $1 \mathrm{E}+00$ & - & $1 \mathrm{E}+02$ & $2 \mathrm{E}+01$ & $2 \mathrm{E}+00$ & - & $2 \mathrm{E}+02$ & $6 \mathrm{E}+01$ & $4 \mathrm{E}+01$ \\
\hline Eco-Sil dope $\left(\mathrm{nmol} / \mathrm{cm}^{2} / \mathrm{d}\right)$ & BDL & $\mathrm{BDL}$ & BDL & $\mathrm{BDL}$ & BDL & BDL & $\mathrm{BDL}$ & $\mathrm{BDL}$ & $\mathrm{BDL}$ & $\mathrm{BDL}$ & $\mathrm{BDL}$ & BDL \\
\hline TF-15 grease $(\mathrm{nmol} / \mathrm{g} / \mathrm{d})$ & - & $2 \mathrm{E}+03$ & - & $2 \mathrm{E}+02$ & - & $3 \mathrm{E}+03$ & - & $1 \mathrm{E}+02$ & - & $9 \mathrm{E}+03$ & - & $3 \mathrm{E}+02$ \\
\hline Loctite sealant $(\mathrm{nmol} / \mathrm{g} / \mathrm{d})$ & - & $1 \mathrm{E}+01$ & - & 7E-01 & - & $1 \mathrm{E}+01$ & - & $4 \mathrm{E}-01$ & - & $3 \mathrm{E}+02$ & - & $1 \mathrm{E}+02$ \\
\hline APT 3 sealant $(\mathrm{nmol} / \mathrm{g} / \mathrm{d})$ & - & $4 \mathrm{E}+03$ & - & $3 \mathrm{E}+02$ & - & $1 \mathrm{E}+04$ & - & $6 \mathrm{E}+02$ & - & $2 \mathrm{E}+04$ & - & $2 \mathrm{E}+03$ \\
\hline
\end{tabular}

Leaching rates expressed as nmol $\mathrm{N}$ leached per $\mathrm{cm}^{2}$ (surface area) per day or $\mathrm{nmol} \mathrm{N}$ leached per gram material per day. $-=$ data not available, $\mathrm{BDL}=$ below detection limit. 